Running head: HAUDENOSAUNEE DEVELOPMENTAL SCIENCE

Towards a Haudenosaunee Developmental Science: Perspectives From the Two Row Wampum

\author{
Jillian Fish \\ Minneapolis VA Health Care System \\ University of Minnesota Medical School
}

Version: October 13, 2021

Status: Under Revision at Infant \& Child Development

Author note. Direct correspondence to Jillian Fish (fishx174@umn.edu), Minneapolis VA Health Care System, Center for Care Delivery and Outcomes Research, One Veterans Drive, Minneapolis, MN, 55417. No funding was provided for the preparation of this manuscript. Data sharing is not applicable to this article as no new data were created or analyzed in this study. 


\begin{abstract}
The Two Row Wampum belt represents a treaty between the Haudenosaunee and Dutch about how the two nations would coexist with each other in the context of settler colonialism. The oral tradition of the Two Row Wampum states that the Haudenosaunee would travel down the river of life in a canoe containing their ways of being and knowing, while the Dutch would travel alongside them in a ship with their own orientations to the world. However, the original principles of the Two Row Wampum contrast with the colonial realities of the Haudenosaunee. In an application of the Two Row Wampum to developmental science, in which the river is the life course, Mainstream developmental science is the ship, and Haudenosaunee developmental science is the canoe, I use the Principles of the Two Row Wampum to propose a Haudenosaunee perspective of the field. I compare this with how Mainstream developmental science dominates the field, marginalizing various Indigenous developmental sciences in a manner similar to the Betrayal of the Two Row Wampum. Though I recommend that Mainstream developmental science returns to the principles of the Two Row Wampum, I demonstrate that Indigenous developmental sciences operate beyond the constraints of developmental psychology by centering Indigenous ontologies and epistemologies to promote Indigenous futures.

Keywords: Haudenosaunee, Indigenous, Two Row Wampum, settler colonialism, human development.
\end{abstract}




\section{Towards a Haudenosaunee Developmental Science: Perspectives From the Two Row}

\section{Wampum}

When I reflect on the role of Indigenous peoples, perspectives, and paradigms in developmental science, the Two Row Wampum belt comes to mind (c. 1613; Rickard, 2011). ${ }^{1}$ According to the oral history of the Haudenosaunee Confederacy (i.e., the Mohawk, Oneida, Onondaga, Cayuga, Seneca, and Tuscarora), the Two Row Wampum belt symbolizes a treaty agreed upon between the Haudenosaunee and Dutch about how the two nations should coexist with each other in light of the formation of settler colonies in Haudenosaunee territory. The belt itself was constructed out of purple and white wampum beads; rows of white beads represent a single river that separates two rows of purple beads representing the Haudenosaunee and Dutch respectively (Onondaga Nation, n.d.; see Figure 1). Per oral tradition, the Haudenosaunee would travel down the river in a canoe containing Haudenosaunee ontologies (i.e., ways of being) and epistemologies (i.e., ways of knowing; Wilson, 2001), while the Dutch would traverse the same river in a ship that carried their own beliefs and knowledge about the world. The Haudenosaunee and Dutch would navigate the river side-by-side as equals, and never interfere with one another's journeys. Growing up on the Tuscarora Nation - the sixth and final tribe to be accepted into the Haudenosaunee Confederacy after migrating from North Carolina to New York as the result of a devastating battle during the Tuscarora War - the orality of the Two Row Wampum was critical to my understanding of Indigenous-settler relations, including self-determination, relationships, and equity (Hill \& Coleman, 2019).

Now as a Tuscarora psychologist, not only do I understand the Two Row Wampum as one of the oldest known Indigenous treaties, but as one of the earliest theories of Haudenosaunee

\footnotetext{
${ }^{1}$ The Two Row Wampum is also known as Gä•sweñta' (in Onondaga; Onondaga Nation, n.d.), Teioháte Kaswenta (in Mohawk), and Tekani teyothata'tye kaswenta (in Cayuga; Hill \& Coleman, 2019).
} 
development - and most neglected. Indeed, the promises of the Two Row Wampum belt stand in stark juxtaposition to the realities of the Haudenosaunee (and Indigenous peoples more broadly) in settler colonial societies past and present (Lowman \& Barker, 2016). Generally speaking, the Dutch honored the Two Row Wampum. However, other European settlers (e.g., the English, French; Hill \& Coleman, 2019) did not, and engaged in mass killings and enslavement of the Haudenosaunee (Goldstein, 2008). The purpose of settler colonialism is, in fact, to eliminate Indigenous peoples through various methods (e.g., genocide, assimilation) in order to acquire land for permanent settlement (Wolfe, 2006). Subsequently, European settlers built societies that settler colonialism continues to be the foundation of (Glenn, 2015; Steinman, 2016). As a result, mainstream ontologies and epistemologies often subjugate Indigenous ones in colonial societies (Duarte \& Belarde-Lewis, 2015; Simpson, 2014), including in developmental science; the implications of which are detrimental, but not definitive, for Indigenous health and well-being. In other words, for the canoe and ship to coexist in the same river, settler colonialism requires that the former to do so on the terms of the latter. Much like my claim that the Two Row Wampum is a Haudenosaunee perspective of the cultural ecology of human development, the betrayal of the treaty similarly provides a powerful commentary on the structural marginalization of Indigenous beliefs and knowledge in the field of developmental psychology (Hill, 2018; Okazaki et al., 2009; Syed et al., 2018).

\section{An Application of the Two Row Wampum to Developmental Science}

While I aspire to a developmental psychology informed by the Two Row Wampum, the state of the discipline is more congruent with its betrayal. For the remainder of this paper, I make beginning efforts to advance a Haudenosaunee developmental science through a brief application of the oral history of the Two Row Wampum. In the following application, the life course is the 
river, Mainstream developmental science is the ship, and Haudenosaunee developmental science is the canoe (see Figure 2). ${ }^{2}$ As I discuss each in turn, I use the original Principles of the Two Row Wampum to provide a Haudenosaunee perspective on that aspect of developmental science, which I contrast with the Betrayal of the Two Row Wampum as a respective critique. Through this brief application, my aim is to offer a commentary on the ontologies and epistemologies in Mainstream developmental science that marginalize and inflict harm on Indigenous peoples, and a potential path for reconciling this through Indigenous developmental psychologies - in this case, a Haudenosaunee developmental science. Consequently, I highlight recommendations for developmental science to return to the Two Row Wampum for a more equitable discipline and conclude with implications of a Haudenosaunee developmental science for Indigenous futures.

\section{The River (The Life Course)}

"Each line of the wampum belt represents each of our laws, governments, languages, cultures, our ways of life. It is agreed that we will travel together, side by each, on the river of life... linked by peace, friendship, forever."

- Jake Edwards, Onondaga Nation (Queally, 2013)

\section{Principles of the Two Row Wampum}

According to the original Principles of the Two Row Wampum, the river and the life course are one and the same - although there are multiple ways to navigate it that are neither superior nor inferior to one another. What is remarkable about the Haudenosaunee's description of traveling down the river alongside the Dutch is the recognition that there are numerous and diverse approaches to living life (Ransom \& Ettenger, 2001). The Haudenosaunee and Dutch were abundantly clear about their respective approaches to traveling down the river being shaped

\footnotetext{
${ }^{2}$ I use the term "mainstream" to describe an ontological and epistemological approach to developmental science that the majority of psychologists adhere to (Toomela, 2014). I do not use the terms "western" or "modern" because both suggest that Indigenous peoples are not of these contexts.
} 
by their beliefs (i.e., ontology) and thoughts about reality (i.e., epistemology; Wilson, 2001; Wilson et al., 2021), as is the case for many cultural groups (Adams et al., 2015). Even in the $17^{\text {th }}$ century, the Two Row Wampum suggests that the Haudenosaunee and Dutch knew that maintaining their own lifeways and having healthy relationships with other lifeways were critical to each of their developmental trajectories. Through respect and friendship, the Haudenosaunee and Dutch generated an ethical developmental landscape, in which they agreed not to impose their ontologies or epistemologies on each other (Ermine, 2007), enabling the Haudenosaunee to make their own decisions about their livelihoods and enact them via self-determination (Tsosie, 2012). Thus, the Principles of the Two Row Wampum describe Haudenosaunee conditions for supporting their development, as well as that of other Indigenous peoples, in the context of settler colonialism. Given developmental science's focus on human growth and development across the lifespan, the metaphor of the river is applicable to psychologists' views of what is important about the life course and what contributes to developmental outcomes.

The Haudenosaunee's perspective of the life course is expansive, including relationships with spiritual beings - not just people, but our ancestors, the environment, and non-humans too (Watts, 2013). During the commemoration of the $400^{\text {th }}$ anniversary of the Two Row Wampum, Hickory Edwards (Onondaga Nation) said "Our ancestors made this great agreement on our behalf 400 years ago. Now is the time to think about people living in the next 400 years" (Mager, 2013). At the same event, Freida Jacques (Clanmother of the Turtle Clan of the Onondaga Nation) described what the Two Row Wampum means for the environment, "An important aspect of this agreement was that we live in the river of life and we all need to take care of it. The environment was a part of this agreement" (Mager, 2013). Both of their remarks underscore Haudenosaunee beliefs about our role in an ecosystem that transcends the earth and present 
moment; our relationships with other people, the environment, and all that we hold sacred affects future generations of the Haudenosaunee, and the kind of ancestors that we will one day become. Learning these foundational Haudenosaunee worldviews is a critical developmental task, which occurs through the oral tradition and language (Fish, 2021). The Haudenosaunee creation story and the Thanksgiving Address are among several narratives that transmit knowledge of our origins, sovereignty, and values. ${ }^{3}$ The Great Law of Peace, in particular, teaches us to treat others with respect, to maintain a democratic society, to use reason to promote peace, and to have a good mind (National Museum of the American Indian, 2009). There are countless other teachings about seasons, sports, regalia, lodging, clans, migration, food, and modern life - all forming a complex ontological and epistemological network that informs our daily lives. Delving into the ontologies and epistemologies of all Indigenous peoples is impossible for a single paper without homogenizing Indigeneity. However, we know from the Two Row Wampum that Haudenosaunee and Indigenous development, at the bare minimum, is culture- and historyspecific.

\section{Betrayal of the Two Row Wampum}

The Haudenosaunee's perspective of the life course predates the White, male developmental psychologists (e.g., Piaget) and scientists (e.g., Darwin) who are credited with forming the field (Beilin, 1992; Charlesworth, 1992). Early developmental theorists like Darwin, Galton, and Pearson have inflicted significant harm on Indigenous peoples via pseudoscience supporting racial differences and eugenics. Developmental psychologists have perpetuated this harm by advancing claims of scientific racism, including that Indigenous peoples are inferior to

\footnotetext{
${ }^{3}$ These teachings were an integral part of my education at Tuscarora Indian School. For example, we regularly recited the Thanksgiving Address in the Tuscarora (Skarù rę?) language to acknowledge all that we are thankful for. One sentence, "Yękwarihuwathá? $\theta$ eh yękwa?ę? úp uneh. Ù:nę čakwa?tikęhra:t" (translated into "We are thankful for Mother Earth"), illustrates our connections to the earth and the importance of honoring her.
} 
White people (Turiel, 2020; Yakushko, 2019) in a clear Betrayal of the Two Row Wampum. Indeed, developmental science has historically considered Indigenous peoples separate and unequal, which has directly impacted Haudenosaunee development. Like countless other Haudenosaunee people, three of my great-grandparents were survivors of Indian boarding schools, which were intended to "Kill the Indian, save the man" (Fish \& Syed, 2018, p. 387). In my great-grandma Lillian Henry’s report card from Carlisle Industrial Indian School, a school administrator initially described her "ability" as "not very good", and refused to return her to my great-great-grandfather for five years (Carlisle Indian School Digital Resource Center, n.d.). Thus, early developmental science supporting racism is complicit in the atrocities of boarding and residential schools, in addition to other efforts to eradicate Indigenous peoples (e.g., forced sterilization). The legacy of this foundation is evident in the developmental literature on Indigenous peoples, which until recently has been contoured by a deficit approach that anchors atypical developmental outcomes in individuals, rather than the conditions of the river (e.g., oppression, colonialism; Syed et al., 2018). Developmental science aligning with perspectives void of culture to promote a universal standard of child and adolescent development (Woodhead, 1999) via individual-level analyses (Jahoda, 1986; Schwartz, 1981) is a devastating Betrayal of the Two Row Wampum. As Burman (2012) described, developmental psychology is "historically and culturally limited" (p. 140) to European and (Anglo) U.S. perspectives that dominate how we understand the life course (Burman, 2017).

There is growing consensus that culture and its organizing features (i.e., ontologies, epistemologies) are integral to the human experience (Cole \& Packer, 2011; García Coll et al., 1996), creating space for developmental scientists to critically consider Indigenous perspectives and theories of human development (Fish et al., 2020; Fitzgerald \& Farrell, 2012), as I am from 
the standpoint of the Haudenosaunee. However, few take into account the role of relationships with spiritual (Willard \& Norenzayan, 2013) and environmental entities (Washinawatok et al., 2017), and non-linear temporality (Amorim, 2017), on Indigenous functioning and development. The Haudenosaunee's perspective of the life course, and the belief and knowledge systems that shape it, have been known to tribal members and descendents for centuries, but it remains largely excluded from the developmental literature (Spicer et al., 2012). A recent exegesis of the writings of Erikson (1963) demonstrates that culture was a prominent feature in his theories on the development of the Sioux and Yurok, in which he alludes to the potential impact of the degree of colonial contact and self-determination on tribes (Syed \& Fish, 2018). Similarly, Piaget was concerned with the context of development (Turiel, 2020), as was Bronfenbrenner (1997), though neither's theorizing was specific to Indigenous peoples, nor was it as detailed as the Haudenosaunee. At best, there are tenuous connections between what the Haudenosaunee articulated about the contextual nature of development at its most basic-level and the scholarship of distinguished developmental psychologists. Consequently, the Betrayal of the Two Row Wampum is the neglect and disregard of Haudenosaunee contributions to human development. Post-humanist critiques of Bronfenbrenner point to the anthropocentric nature of his theorizing (Elliott \& Davis, 2018), which applies to Erikson and Piajet too; a gap in the developmental literature that could have easily been filled by the Haudenosaunee long ago (see Fish \& Syed, 2018 for an Indigenous critique of Bronbrenner). Like European settlers who did not think Haudenosaunee ways of being and knowing were important, the Betrayal of the Two Row Wampum is the refusal to see beyond mainstream perspectives of the river in developmental science.

\section{The Ship (Mainstream Developmental Science)}


"And in the boat, likewise, are the European language, customs, traditions, and law. We have said, 'Please don't get out of your boat and try to steer our canoe. And we won't get out of our canoe and try to steer your boat.'"

- G. Peter Jemison, Seneca Nation (Public Broadcasting Service, n.d.)

\section{Principles of the Two Row Wampum}

Why does developmental psychology have such a narrow view of the life course?

Developmental science is disproportionately skewed towards Mainstream developmental science in what I consider a misalignment with a Haudenosaunee take on the field. According to the Principles of the Two Row Wampum, the ship is Mainstream developmental science, which contains mainstream ontologies (i.e., beliefs about the life course) and epistemologies (i.e., how to study it). Both ontology and epistemology influence research methodology and axiology, all of which coalesce to form a research paradigm (Ponterotto, 2005). In Mainstream developmental science, research studies tend to be quantitative in nature (Syed et al., 2018). Prevailing research paradigms include positivism and post-positivism, and to a far lesser extent constructivism and critical theory (see Wilson, 2001 for a review). Positivism and postpositivism assert that there is a true reality that can be objectively known (to an extent depending on the research paradigm), whereas constructivism and critical theory believe there are multiple realities that are socially constructed and as a result, can only be subjectively known (Ponterotto, 2005). The research paradigms that are given preference in developmental psychology (positivism, postpositivism) do not consider researcher axiology (i.e., values, emotions) as an important part of the research process. Taken together, it is no surprise that Mainstream developmental science focuses on presumed universal and individual processes with little regard for context (Vélez-Agosto et al., 2017). What makes the ship's approach to development "mainstream" is that its orientations to researching the lifespan are, by and large, rooted in the perspectives of the dominant members of 
Western Europe and the U.S., who continue to dominate the field of developmental psychology (Syed et al., 2018).

The Principles of the Two Row Wampum indicate that the Haudenosaunee were well aware that the ship's orientations differed from the canoe's. This was not a major concern, as long as the ship respected the conditions agreed upon in the Two Row Wampum. That is, the ship should not impose its beliefs and knowledge systems onto the canoe for the sake of promoting a non-hierarchical, and interdependent yet autonomous, environment (Hill \& Coleman, 2019). This was an intentional design of the Two Row Wampum. For instance, the Dutch initially preferred to refer to the Haudenosaunee as "sons." However, the Haudenosaunee objected to such an arrangement because of its hierarchical implications (Onondaga Nation, n.d.). Following the recommendations of the Two Row Wampum means that like the ship, Mainstream developmental science should not impose its orientations onto a Haudenosaunee approach to developmental science. Further, Mainstream developmental science must respect differences between the two as contributing equal value to the study of the life course. To create and maintain the ethical developmental landscape of the Two Row Wampum, it is imperative that Mainstream developmental science adheres to research principles developed from the treaty, which center the dialogical nature of relationships, place-conscious ceremony, equity between distinct groups of people, individual differences and diversity, and sharing knowledge (p. 341, Hill \& Coleman, 2019). ${ }^{4}$ These principles do not affect Mainstream developmental science per se, but instead, have the potential to promote an equal and fair relationship with Haudenosaunee and other Indigenous developmental sciences in the field.

\section{Betrayal of the Two Row Wampum}

\footnotetext{
${ }^{4}$ Hill \& Coleman (2019) describe each of these principles in depth. Place-conscious ceremony refers to engaging in ceremony to create a respectful and healthy relationship between researchers, participants, and more-than-human entities.
} 
In contrast to the Principles of the Two Row Wampum, developmental science reflects an overrepresentation of the ship: developmental science is Mainstream developmental science in terms of people, perspectives, and paradigms. As Hill \& Coleman (2019) note, "This is where the main betrayal of the Two Row has taken place. The settler societies appeared to be all about imposition, despite this treaty" (p. 351). In the Betrayal of the Two Row Wampum, European settlers impose their ontologies and epistemologies onto the Haudenosaunee, positioning their approach to navigating life as superior. Likewise, Mainstream developmental science dominates the study of the life course - it is often the only vessel on the river (Figure 3). Developmental science privileges (post)positivistic research paradigms despite their limited ontological, epistemological, and methodological approaches - and total lack of axiological consideration (Wilson, 2001). Other mainstream research paradigms (e.g., constructivism, critical theory) are more flexible, have a greater axiological orientation, and lend themselves better to qualitative research, but are less prevalent and still reflect mainstream ontologies and epistemologies (Fish \& Syed, 2020). Though Indigenous developmental scientists gravitate towards these paradigms (Whitesell et al., 2018), the dearth of empirical research that is actually published on Indigenous development in developmental journals is (post)positivistic in nature (e.g., Cvencek et al., 2017). Instead, developmental outlets tend to include more articles on Indigenous-focused theories and concepts (e.g., Markstrom, 2011). All of which is woefully inadequate in comparison to what could be possible if developmental science privileged Haudenosaunee and other Indigenous peoples, perspectives, and paradigms to the same extent as mainstream ones.

Similarly, Haudenosaunee and other Indigenous developmental sciences are excluded elsewhere in the profession - like in organizations and graduate programs. Despite having multiple caucuses dedicated to marginalized youth (e.g., Asian Caucus, Black Caucus, Latinx 
Caucus, Sexual Orientation and Gender Identity/Expression Caucus), the Society for Research on Child Development (SRCD) lacks a Native American and Indigenous Caucus. What I'm asking us to critically examine here is why? The most common response is that it is the responsibility of SRCD members to propose and form a new caucus. Some readers might even be wondering, "Wait, is there such a thing as a Haudenosaunee (or Indigenous) developmental science?" Again, the Two Row Wampum necessitates that we consider the conditions of the river and the positions of the vessels on it. There is a Haudenosaunee and countless other Indigenous developmental sciences, but developmental science as a field is structured to alienate Indigenous ontologies and epistemologies from the river in favor of Mainstream developmental science. This phenomenon is not exclusive to SRCD, but is a trend of most professional societies and doctoral programs in developmental psychology, which until recent years were devoid of Indigeneity. In a modern form of colonization, the Betrayal of the Two Row Wampum is that Haudenosaunee developmental scientists (prospective and beyond) must trade in their canoe for a ship to be included in developmental psychology at all.

\section{The Canoe (Haudenosaunee Developmental Science)}

"The future generations will look to us, asking, what did you do to keep the ship and the canoe on a healthy course on the River of Life?"

- Rick W. Hill Sr (Tuscarora Nation) and Daniel Coleman (2019, p. 255)

\section{Principles of the Two Row Wampum}

The Haudenosaunee did not envision our people (or other Indigenous peoples) abandoning their canoes (or other Indigenous vessels) to navigate the river - and we haven't. The Principles of the Two Row Wampum position the canoe (i.e., Haudenosaunee developmental science) as equal to the ship, which comprises Indigenous peoples, perspectives, and paradigms. Peoples include Indigenous developmental scientists and research samples that reflect our 
heterogeneity, and tribal and geographic diversity. Perspectives refers to Indigenous-takes on mainstream paradigms, concepts, and processes (Fish, 2020; Fish \& Counts 2020; Galliher et al., 2012; Thompson et al., 2012), whereas Indigenous paradigms are the product of Indigenous ontologies, epistemologies, methodologies, and axiologies (see Hart, 2010; Peltier, 2018; Wilson, 2008). According to the Principles of the Two Row Wampum, developmental science should ideally include each feature to a similar extent as their mainstream counterparts. This is equality. Additionally, each feature should be supported, respected, and valued in their own right. This is equity. Among the Haudenosaunee in particular, there is a growing literature consisting of Haudenosaunee point of views on research processes (e.g., Hill \& Coleman, 2019; Santiago-Rivera et al., 1998) and developmental concepts that are distinct to the Haudenosaunee (e.g., Haudenosaunee imagination; Sheridan \& Longboat, 2006). Not only does this literature include samples of Haudenosaunee people (e.g., Waterman, 2012) but it positions us as researchers as well, enabling us to leverage Haudenosaunee ontologies and epistemologies to form our own research paradigms (e.g., Freeman \& Van Katwyk, 2020) to more effectively study key aspects of our development. This includes the relationship between Haudenosaunee teachings and culture-based activities and a) youth identity development and well-being (Whitlow et al., 2019), b) notions of holistic health (Jacobs, 2018), and c) Haudenosaunee grandmothers culturally socializing their grandchildren (Hill, 2020). Each contribute valuable knowledge to developmental science about the significance of Haudenosaunee culture for positive growth and adjustment across the lifespan.

The Principles of the Two Row Wampum are the foundation of healthy relationships between the Haudenosaunee and European settlers like the Dutch, enabling the canoe to thrive via autonomy and self-determination. Honoring the Principles of the Two Row Wampum in 
developmental science means creating the conditions for Haudenosaunee and Indigenous developmental sciences to not merely exist, but to flourish along the river. As Haudenosaunee scholars note, relationality is the source of generating, sustaining, and promoting an equitable and just coexistence. While this includes establishing reciprocal relationships between the ship and canoe (or Mainstream and Haudenosaunee developmental science; Allen et al., 2012), it also refers to harnessing a broader perspective about the connections between Indigenous lifeways and the well-being of all that is on this earth (and beyond it). Ergo, a Haudenosaunee vision of the canoe entails having several canoes - or Indigenous developmental sciences - on the river that adequately reflect the heterogeneity of Indigeneity. Most importantly, having multiple canoes on the river empowers Indigenous communities and the larger ecosystem to thrive by way of developmental psychologies that are not just for us, but that are also by us. Glimmers of a Haudenosaunee vision of the canoe can be seen in a special section of Child Development Perspectives (Sarche \& Whitesell, 2012) in which Indigenous and non-Indigenous researchers foreground axiology and relationality to advance various Indigenous developmental sciences that promote the health and wellness of Indigenous communities. The inclusion of such is generally more of an outlier than the norm in developmental science (Hartmann et al., 2013). However, it provides insights into how Indigenous and non-Indigenous developmental scientists are using ethical relations to create a more equitable developmental psychology by changing the space between distinct groups of researchers, in addition to the space available to Indigenous developmental sciences in the field.

\section{Betrayal of the Two Row Wampum}

Thus far, I have demonstrated that mainstream and Haudenosaunee beliefs and knowledge about human development inform their respective approaches to studying the lifespan 
(i.e., Mainstream and Haudenosaunee developmental science). Furthermore, I have illustrated that the structure of the former subjugates and marginalizes the latter. This, too, characterizes the Betrayal of the Two Row Wampum when it comes to the canoe. Haudenosaunee and Indigenous developmental sciences are seen as inferior and invaluable to their Mainstream counterpart in a remnant of settler colonialism. It is not that canoes are never allowed on the river. They are, but only on the conditions put forth by the ship (or on rare occasions). One common misconception of colonialism is that Indigenous peoples lack agency, when in fact, Indigenous communities make difficult decisions to ensure Indigenous futures (Fish, 2018). In 1713, my ancestors chose to migrate over 1,300 miles from our homelands in North Carolina to the Great Lakes region as a result of ongoing settler violence during the Tuscarora War, which is where my community, the Tuscarora, continues to live today. We might be excluded from the river, but Haudenosaunee developmental science forges its own path, as do other Indigenous developmental sciences. A river channel is a smaller river that branches off and flows away from the main river when there are too many barriers preventing water flow at the river's mouth. Although the Betrayal of the Two Row Wampum points to various barriers to an equitable coexistence between Mainstream and Indigenous developmental sciences, the nature of river channels offer insight into our survivance - that is, the endurance, existence, and resistance of Indigenous ontologies and epistemologies (Vizenor, 2008). Our ways of being and knowing do not cease to exist. Rather, they find another way to (Figure 3).

Haudenosaunee and other Indigenous developmental sciences exist beyond the current limitations of developmental psychology that I have described here. There is a talented cadre of Indigenous and non-Indigenous researchers (who are not necessarily developmental scientists or in developmental psychology programs) that leverage and engage with relationality, traditional 
and place-based knowledge, cultural practices and beliefs, and language to support Indigenous development in the context of the U.S. (Bang et al., 2007; Carter et al., 2007; Cwik et al., 2019; Elliott-Groves, 2019; Pugh et al., 2019; Sarche et al., 2017; Sittner et al., 2021; Walls et al., 2020; Whitesell et al., 2015). In addition to the growing body of literature on Haudenosaunee development that I mentioned earlier, there is excellent scholarship on the developmental experiences of various Indigenous communities that inform their own version of an Indigenous developmental science. In Canada in particular, there is a vast swath of empirical research on First Nations' health and development. Several studies have pointed to the negative health effects of residential schools on the First Nations, Métis, and Inuit (Wilk et al., 2017). Simultanously, other research has illustrated the positive health effects of cultural connectedness among Métis and Inuit youth (Snowshoe et al., 2015), and of cultural continuity as a protective factor for suicide (Chandler \& Lalonde, 1998) and other negative health outcomes (Oster et al., 2014). There is also strengths-based and culture-focused research about various factors that promote healthy Māori development - including connections to the land (Hond et al., 2019) and traditional cultural practices (Penehira \& Doherty, 2013). Although this only reflects some of the literature, it points to the existence of First Nations, Inuit, Métis, and Māori developmental sciences despite the unequitable conditions of the river. Through self-determination, Indigenous developmental sciences will continue to find the environments optimal for Indigenous peoples and our development.

\section{Returning to the Two Row Wampum in Developmental Science}

When I said earlier, “When I reflect on the role of Indigenous peoples, perspectives, and paradigms in developmental science, the Two Row Wampum belt comes to mind", it is because I see great potential for what developmental science could be in comparison to what it currently is. 
So too do other Indigenous peoples, specifically the Haudenosaunee. After illustrating the extent that developmental science has broken the conditions of the Two Row Wampum, one question remains: how can developmental science return to the principles that the Haudenosaunee and Dutch agreed would promote an equitable coexistence in the context of settler colonialism? I have seriously contemplated if developmental science can return to values it has not historically embodied but now seemingly aspires to, and the answer is anything but simple. Returning to the Two Row Wampum means more than merely going back, especially for a developmental science that is guilty of committing epistemic violence that has sanctioned the ongoing domination of Indigenous peoples in society. Returning to the Two Row Wampum entails restoring Indigenous and settler relations in developmental science to the vision of the Haudenosaunee, which starts with reconciliation. For Haudenosaunee and Mainstream developmental science to coexist on the same river under fair and equitable conditions, developmental science must make significant efforts to understand and repair the harm it has caused Indigenous peoples and communities. In accordance with the Two Row Wampum, this should occur in dialogue with Indigenous peoples, including those inside (e.g., developmental scientists) and outside (e.g., community members) of the profession, to glean insight into how developmental science can be restructured to serve the best interests of Indigenous peoples and to discern respectful steps for doing so moving forward. Examples of endeavors that developmental science might consider pursuing in relationship with Indigenous peoples include developing related curricula, recruiting Indigenous developmental scientists as faculty (and graduate students), publishing and funding more research on Indigenous developmental sciences, and creating opportunities for dialogue (e.g., task forces, professional organizations) regarding Indigenous developmental sciences. This is sowing the seeds of justice. 
Although developmental science cannot erase its settler colonial foundation, it can begin again with Indigeneity at its fore. Whether or not such efforts are sufficient enough for the canoe to venture back onto the river is up to Indigenous developmental scientists and the communities we serve. Given that settler colonialism is a power structure that seeks to subjugate Indigeneity in all its forms, dismantling the colonial infrastructure of the discipline would require a major shift in how mainstream developmental scientists relate to knowledge, the environment, and Indigenous presence. However, dismantling all remnants of settler colonialism is necessary so long as developmental science wants to be allies of Indigenous futures. To reiterate one of the perspectives from the Two Row Wampum, a colonial developmental science is detrimental but not definitive for Indigenous well-being. Though what happens on the river has implications for the Haudenosaunee and other Indigenous communities, being excluded from it has not prevented us from thriving. Should developmental science continue to stay the course of the Betrayal of the Two Row Wampum, I expect that Indigenous communities will persevere through our own efforts supporting our health and development. Similarly, Indigenous developmental scientists may find the attempts of settler developmental scientists to reconcile inadequate to reasonably return to the river. For those who persist in the river channel then, Returning to the Two Row Wampum might mean reclaiming the knowledge that developmental science has and always will be Indigenous.

\section{Conclusions: Indigenous Futures in Developmental Science}

Through a novel application of the Two Row Wampum belt, a longstanding treaty between the Haudenosaunee and Dutch, I described various Haudenosaunee principles that are critical to Haudenosaunee (and Indigenous) development and well-being in settler colonial societies, including relationality. By contrasting this with the state of the field, I demonstrated how developmental science violates these principles by overwhelmingly and disproportionately 
privileging mainstream ways of being and knowing. Instead of contributing to an equitable and relational discipline where Haudenosaunee developmental science can leverage our orientations to the world to promote healthy developmental trajectories, Mainstream developmental science constrains Haudenosaunee developmental science's ability to do so. Consequently, Mainstream developmental science must engage in a radical self-evaluation and take action-oriented steps to restore the just relations of the Two Row Wampum to support all Indigenous developmental sciences. In spite of the current conditions of the river, Indigenous developmental sciences will continue to foster positive developmental outcomes that center Indigenous ontologies and epistemologies, perhaps as a field of its own. Thus, if you are an aspiring Indigenous developmental scientist standing on the bank of a river in search of a canoe but you only see a ship, make sure to look a little bit further - we'll meet you there, where we are reimagining Indigenous futures beyond the limitations of Mainstream developmental science. 


\section{References}

Adams, G., Dobles, I., Gomez, L. H., Kurtis , T., \& Molina, L. E. (2015). Decolonizing psychological science: Introduction to the special thematic section. Journal of Social and Political Psychology, 3, 1-7. http://dx.doi.org/10.5964/jspp.v3i1.564

Allen, J., Mohatt, G. V., Markstrom, C. A., Byers, L., \& Novins, D. K. (2012). “Oh no, we are just getting to know you": The relationship in research with children and youth in Indigenous communities. Child Development Perspectives, 6, 55-60. https://doi.org/10.1111/j.1750-8606.2011.00199.x

Amorim, T. (2017). A new conceptualization of development in child and youth care. CYCOnline: e-Journal of the International Child and Youth Care Network, 217, 39-44.

Bang, M., Medin, D. L., \& Atran, S. (2007). Cultural mosaics and mental models of nature. Proceedings of the National Academy of Sciences, 104, 13868-13874. https://doi.org/10.1073/pnas.0706627104

Beilin, H. (1992). Piaget's enduring contribution to developmental psychology. Developmental Psychology, 28, 191-204. https://doi.org/10.1037/0012-1649.28.2.191

Bronfenbrenner, U. (1997). Ecological models of human development. In M. Gauvain \& M. Cole (Eds.), Readings on the development of children (2nd Ed.). (pp. 37-43). NY: Freeman. (Reprinted from International encyclopedia of education, Vol. 3, 2nd. ed., pp. 1643-1647, 1994, Oxford, England: Elsevier).

Burman, E. (2012). Un/thinking children in development: A contribution from northern antidevelopmental psychology. The Journal of the Hellenic Psychological Society, 19, 125-143.

Burman, E. (2017). Deconstructing developmental psychology. Routledge. 
Carlisle Indian School Digital Resource Center (n.d.). Lillian Henry student file. Carlisle Indian School. https://carlisleindian.dickinson.edu/student_files/lillian-henry-student-file

Carter, S., Straits, K. J., \& Hall, M. (2007). Project Venture: Evaluation of an experiential, culturally based approach to substance abuse prevention with American Indian youth. Journal of Experimental Education, 29, 397-400. https://doi.org/10.1177/105382590702900315

Chandler, M. J., \& Lalonde, C. (1998). Cultural continuity as a hedge against suicide in Canada's First Nations. Transcultural Psychiatry, 35, 191-219.

Charlesworth, W. R. (1992). Darwin and developmental psychology: Past and present. Developmental Psychology, 28, 5-16. https://doi.org/10.1037/0012-1649.28.1.5

Cole, M., \& Packer, M. (2011). Culture in development. In M. H. Bornstein \& M. E. Lamb (Eds.), Developmental science: An advanced textbook (p. 51-107). Psychology Press.

Cvencek, D., Fryberg, S. A., Covarrubias, R., \& Meltzoff, A. N. (2018). Self-concepts, selfesteem, and academic achievement of minority and majority North American elementary school children. Child Development, 89, 1099-1109. https://doi.org/10.1111/cdev.12802

Cwik, M., Goklish, N., Masten, K., Lee, A., Suttle, R., Alchesay, M., O’Keefe, V., \& Barlow, A. (2019). "Let our apache heritage and culture live on forever and teach the young ones": Development of the elders' resilience curriculum, an upstream suicide prevention approach for American Indian Youth. American Journal of Community Psychology, 64, 137-145. https://doi.org/10.1002/ajcp.12351

Duarte, M. E., \& Belarde-Lewis, M. (2015). Imagining: Creating spaces for Indigenous ontologies. Cataloging \& Classification Quarterly, 53, 677-702. 
Elliott, S., Davis, J.M. (2018) Challenging taken-for-granted ideas in early childhood education: A critique of Bronfenbrenner's ecological systems theory in the age of post-humanism. In Cutter-Mackenzie A., Malone K., Barratt Hacking E. (Eds.) Research Handbook on Childhoodnature. Springer International Handbooks of Education. https://doi.org/10.1007/978-3-319-51949-4_60-2

Elliott-Groves, E. (2019). A culturally grounded biopsychosocial assessment utilizing Indigenous ways of knowing with the Cowichan Tribes. Journal of Ethnic \& Cultural Diversity in Social Work, 28, 115-133. https://doi.org/10.1080/15313204.2019.1570889

Erikson, E. (1963). Childhood and society. W. W. Norton \& Company.

Ermine, W. (2007). The ethical space of engagement. Indigenous Law Journal, 6, 193-203.

Fish, J. (2018, August). Honoring indigenous cultures and histories [Video]. TED. https://www.ted.com/talks/jill_fish_honoring_indigenous_cultures_and_histories?langua $\mathrm{ge}=\mathrm{en}$

Fish, J. (2020). Systems of cultural representation: An examination of Native American identity and cultural representations through digital stories (28026141) [Doctoral Dissertation, University of Minnesota]. ProQuest Dissertations Publishing.

Fish, J. (2021, January 26). Winter in the long house [Blog]. The Great Northern Festival. https://thegreatnorthernfestival.com/blog/winter-in-the-longhouse

Fish, J., \& Counts, P. K. (2021). "Justice for Native People, Justice for Native Me”: Using digital storytelling methodologies to change the master narrative of Native American peoples. In K. McLean (Eds.) Cultural methods in psychology: Describing and transforming cultures (p. 237-272). Oxford University Press. 
Fish, J., Hirsch, G., \& Syed, M. (2020). “Walking in two worlds”: Towards an Indigenist ecological systems model for group therapy. PsyArXiv. https://doi.org/10.31219/osf.io/xb5m2

Fish, J., \& Syed, M. (2018). Native Americans in higher education: An ecological systems perspective. Journal of College Student Development, 59, 387-403. https://doi.org/10.1353/csd.2018.0038

Fish, J., \& Syed, M. (2021). Digital storytelling methodologies: Recommendations for a participatory approach to engaging underrepresented communities in counseling psychology research. Journal of Counseling Psychology, 68, 271-285. https://doi.org/10.1037/cou0000532

Fitzgerald, H. E., \& Farrell, P. (2012). Fulfilling the promise: Creating a child development research agenda with Native communities. Child Development Perspectives, 6, 75-78. https://doi.org/10.1111/j.1750-8606.2011.00216.x

Freeman, B., \& Van Katwyk, T. (2020). Navigating the waters: Understanding allied relationships through a Tekéni Teyohà: ke Kahswénhtake Two Row research paradigm. Journal of Indigenous Social Development, 9, 60-76.

Galliher, R. V., Tsethlikai, M. M., \& Stolle, D. (2012). Perspectives of Native and non-Native scholars: Opportunities for collaboration. Child Development Perspectives, 6, 66-74. https://doi.org/10.1111/j.1750-8606.2011.00200.x

García Coll, C., Crnic, K., Lamberty, G., Wasik, B. H., Jenkins, R., Garcia, H. V., \& McAdoo, H. P. (1996). An integrative model for the study of developmental competencies in minority children. Child Development, 67, 1891-1914. https://doi.org/10.1111/j.14678624.1996.tb01834.x 
Glenn, E. N. (2015). Settler colonialism as structure: A framework for comparative studies of US race and gender formation. Sociology of Race and Ethnicity, 1, 52-72. https://doi.org/10.1177/2332649214560440

Goldstein, A. (2008). Where the nation takes place: Proprietary regimes, antistatism, and US settler colonialism. South Atlantic Quarterly, 107, 833-861. https://doi.org/10.1215/00382876-2008-019

Hart, M. A. (2010). Indigenous worldviews, knowledge, and research: The development of an indigenous research paradigm. Journal of Indigenous Social Development, 1, 1-16.

Hartmann, W. E., Kim, E. S., Kim, J. J., Nguyen, T. U., Wendt, D. C.,Nagata, D. K., \& Gone, J. P. (2013). In search of cultural diversity revisited: Recent publication trends in crosscultural and ethnic minority psychology. Review of General Psychology, 17, 243-254. http://dx.doi.org/10.1037/a0032260

Hill, L. (2020). 'You Know What You Know': An Indigenist methodology with Haudenosaunee grandmothers. Journal of Indigenous Social Development, 9, 1-18.

Hill, R. (2018). View from the canoe vs. the View from the ship: The art of alliance. $a b$ Original, 2, 141-150.

Hill Sr, R. W., \& Coleman, D. (2019). The two row wampum-covenant chain tradition as a guide for Indigenous-university research partnerships. Cultural Studies $\leftrightarrow$ Critical Methodologies, 19, 339-359. https://doi.org/10.1177/1532708618809138

Hond, R., Ratima, M., \& Edwards, W. (2019). The role of Māori community gardens in health promotion: a land-based community development response by Tangata Whenua, people of their land. Global Health Promotion, 26, 44-53. 
Jacobs, B. K. (2018). Impacts of industrial and resource development on the wholistic health of Akwesasronon: A human responsibility/rights solution (Unpublished doctoral thesis). University of Calgary, Calgary, AB. http://hdl.handle.net/1880/108777

Jahoda, G. (1986). A cross-cultural perspective on developmental psychology. International Journal of Behavioral Development, 9, 417-437. https://doi-org.ezp1.lib.umn.edu/10.1177/016502548600900402

Lowman, E. B., \& Barker, A. (2016). Settler: Identity and colonialism in 21st century Canada. Fernwood Publishing. http://hdl.handle.net/2299/17822

Mager, A. (2013, August 7). Historic Two Row journey ends in NYC on August $9^{\text {th }}$. Two Row Wampum Renewal Campaign. https://honorthetworow.org/historic-two-row-journeyends-in-nyc-on-august-9th/

Markstrom, C. A. (2011). Identity formation of American Indian adolescents: Local, national, and global considerations. Journal of Research on Adolescence, 21, 519-535. https://doi.org/10.1111/j.1532-7795.2010.00690.x

National Museum of the American Indian. (2009). Haudenosaunee guide for educators. National Museum of the American Indian. https://americanindian.si.edu/sites/1/files/pdf/education/HaudenosauneeGuide.pdf Okazaki, S., David, E. J. R., \& Abelmann, N. (2008). Colonialism and psychology of culture. Social and Personality Psychology Compass, 2, 90-106. https://doi.org/10.1111/j.17519004.2007.00046.x

Onondaga Nation (n.d.). Two row wampum - gä•sweñta'. Onondaga Nation. https://www.onondaganation.org/culture/wampum/two-row-wampum-belt-guswenta/ 
Oster, R. T., Grier, A., Lightning, R., Mayan, M. J., \& Toth, E. L. (2014). Cultural continuity, traditional Indigenous language, and diabetes in Alberta First Nations: A mixed methods study. International Journal for Equity in Health, 13, 1-11.

Peltier, C. (2018). An application of two-eyed seeing: Indigenous research methods with participatory action research. International Journal of Qualitative Methods, 17, 1-12.

Penehira, M., \& Doherty, L. (2013). Tu mai te oriori, nau mai te hauora! A Kaupapa Māori approach to infant mental health: Adapting mellow parenting for Māori mothers in Aotearoa, New Zealand. Pimatisiwin, 10, 367-382.

Ponterotto, J. G. (2005). Qualitative research in counseling psychology: A primer on research paradigms and philosophy of science. Journal of Counseling Psychology, 52, 126-136. https://doi.org/10.1037/0022-0167.52.2.126

Public Broadcasting Serivce (n.d.). Two Row Wampum: Symbol of sovereignty, metaphor for life. http://www.pbs.org/warrior/content/timeline/hero/wampum.html

Pugh, P., McGinty, M., \& Bang, M. (2019). Relational epistemologies in land-based learning environments: reasoning about ecological systems and spatial indexing in motion. Cultural Studies of Science Education, 14, 425-448. https://doi.org/10.1007/s11422-019$\underline{09922-1}$

Queally, J. (2013, August 9). Two Row paddlers arrive to 'honor and renew' Indigenous treaties of peace. Common Dreams. https://www.commondreams.org/news/2013/08/09/two-rowpaddlers-arrive-honor-and-renew-indigenous-treaties-peace

Ransom, J. W., \& Ettenger, K. T. (2001). 'Polishing the Kaswentha': a Haudenosaunee view of environmental cooperation. Environmental Science \& Policy, 4, 219-228. https://doi.org/10.1016/S1462-9011(01)00027-2 
Rickard, J. (2011). Visualizing sovereignty in the time of biometric sensors. South Atlantic Quarterly, 110, 465-486. https://doi-org.ezp2.lib.umn.edu/10.1215/00382876-1162543

Santiago-Rivera, A. L., Skawennio Morse, G., Hunt, A., \& Lickers, H. (1998). Building a community-based research partnership: Lessons from the Mohawk Nation of Akwesasne. Journal of Community Psychology, 26, 163-174.

Sarche, M., Tafoya, G., Croy, C. D., \& Hill, K. (2017). American Indian and Alaska Native boys: Early childhood risk and resilience amidst context and culture. Infant Mental Health Journal, 38, 115-127. https://doi.org/10.1002/imhj.21613

Sarche, M. C., \& Whitesell, N. R. (2012). Child development research in North American Native communities_-looking back and moving forward: Introduction. Child Development Perspectives, 6, 42-48. https://doi.org/10.1111/j.1750-8606.2011.00218.x

Schwartz, T. (1981). The acquisition of culture. Ethos, 9, 4-17.

Sheridan, J., \& Longboat, R. H. C. T. S. D. (2006). The Haudenosaunee imagination and the ecology of the sacred. Space and Culture, 9, 365-381.

Simpson, A. (2014). Mohawk interruptus: Political life across the borders of settler states. Durham, NC: Duke University Press.

Sittner, K. J., Hautala, D. S., \& Walls, M. L. (2021). Conjoint adolescent developmental trajectories of alcohol and marijuana use and early adult outcomes among North American Indigenous people. Addictive Behaviors, 114, 1-7. https://doi.org/10.1016/j.addbeh.2020.106758

Snowshoe, A., Crooks, C. V., Tremblay, P. F., Craig, W. M., \& Hinson, R. E. (2015). Development of a cultural connectedness scale for First Nations youth. Psychological Assessment, 27, 249-259. 
Spicer, P., LaFramboise, T., Markstrom, C., Niles, M., West, A., Fehringer, K., Grayson, L., \& Sarche, M. (2012). Toward an applied developmental science for Native children, families, and communities. Child Development Perspectives, 6, 49-54. https://doi.org/10.1111/j.1750-8606.2011.00212.x

Steinman, E. W. (2016). Decolonization not inclusion: Indigenous resistance to American settler colonialism. Sociology of Race and Ethnicity, 2, 219-236. https://doi.org/10.1177/2332649215615889

Syed, M., \& Fish, J. (2018). Revisiting Erik Erikson’s legacy on culture, race, and ethnicity. Identity, 18, 274-283. https://doi.org/10.1080/15283488.2018.1523729

Syed, M., Santos, C., Yoo, H. C., \& Juang, L. P. (2018). Invisibility of racial/ethnic minorities in developmental science: Implications for research and institutional practices. American Psychologist, 73, 812-826. http://dx.doi.org/10.1037/amp0000294

Thompson, N. L., Whitesell, N. R., Galliher, R. V., \& Gfellner, B. M. (2012). Unique challenges of child development research in sovereign nations in the United States and Canada. Child Development Perspectives, 6, 61-65. https://doi.org/10.1111/j.1750$\underline{8606.2011 .00186 . x}$

Toomela A. (2014) Mainstream psychology. In: Teo T. (Eds.) Encyclopedia of Critical Psychology. Springer. https://doi.org/10.1007/978-1-4614-5583-7_667

Tsosie, R. (2012). Indigenous peoples and epistemic injustice: Science, ethics, and human rights. Wash. L. Rev., 87, 1133-1201. https://digitalcommons.law.uw.edu/wlr/vol87/iss4/5

Turiel, E. (2020). Eugenics, prejudice, and psychological research. Human Development, 64, 103-107. 
Vélez-Agosto, N. M., Soto-Crespo, J. G., Vizcarrondo-Oppenheimer, M., Vega-Molina, S., \& García Coll, C. (2017). Bronfenbrenner's bioecological theory revision: Moving culture from the macro into the micro. Perspectives on Psychological Science, 12, 900-910. https://doi.org/10.1177/1745691617704397

Vizenor, G. (2008). Survivance: Narratives of native presence. U of Nebraska Press.

Walls, M., Sittner, K. J., Whitbeck, L. B., Herman, K., Gonzalez, M., Elm, J. H., Hautala, D., Dertinger, M., \& Hoyt, D. R. (2020). Prevalence of mental disorders from adolescence through early adulthood in American Indian and First Nations communities. International Journal of Mental Health and Addiction, 1-15. https://doi.org/10.1007/s11469-020$\underline{00304-1}$

Washinawatok, K., Rasmussen, C., Bang, M., Medin, D., Woodring, J., Waxman, S., Marin, A., Gurneau, J., \& Faber, L. (2017) Children's play with a forest diorama as a window into ecological cognition. Journal of Cognition and Development, 18, 617-632. https://doi.org/10.1080/15248372.2017.1392306

Waterman, S. J. (2012). Home-going as a strategy for success among Haudenosaunee college and university students. Journal of Student Affairs Research and Practice, 49, 193-209.

Watts, V. (2013). Indigenous place-thought and agency amongst humans and non humans (First Woman and Sky Woman go on a European world tour!). Decolonization: Indigeneity, Education \& Society, 2, 20-34.

Whitesell, N. R., Sarche, M., Keane, E., Mousseau, A. C., \& Kaufman, C. E. (2018). Advancing scientific methods in community and cultural context to promote health equity: Lessons from intervention outcomes research with American Indian and Alaska Native 
communities. American Journal of Evaluation, 39, 42-57. https://doi.org/10.1177/1098214017726872

Whitesell, N. R., Sarche, M., Trucksess, C., \& Tribal Early Childhood Research Center Swyc Community Of Learning. (2015). The survey of well-being of young children: Results of a feasibility study with American Indian and Alaska Native communities. Infant Mental Health Journal, 36, 483-505. https://doi.org/10.1002/imhj.21526

Whitlow, K. B., Oliver, V., Anderson, K., Brozowski, K., Tschirhart, S., Charles, D., \& Ransom, K. (2019). Yehyatonhserayenteri: A Haudenosaunee model for onkwehon: We (Indigenous) education. Canadian Journal of Education, 42, 553-575.

Wilk, P., Maltby, A., \& Cooke, M. (2017). Residential schools and the effects on Indigenous health and well-being in Canada - a scoping review. Public Health Reviews, 38, 1-23.

Willard, A. K., \& Norenzayan, A. (2013). Cognitive biases explain religious belief, paranormal belief, and belief in life's purpose. Cognition 129, 379-391. https://doi.org/10.1016/j.cognition.2013.07.016

Wilson, S. (2001). What is an indigenous research methodology? Canadian Journal of Native Education, 25, 175-179.

Wilson, S. (2008). Research is ceremony: Indigenous research methods. Fernwood Publishing.

Wilson, S., Breen, A. V., DuPré, L. (2021). Mining for culture or researching for justice? Unsettling psychology through Indigenist conversation. In K. McLean (Eds.) Cultural methods in psychology: Describing and transforming cultures (p. 410-426). Oxford University Press.

Wolfe, P. (2006). Settler colonialism and the elimination of the Native. Journal of Genocide Research, 8, 387-409. https://doi.org/10.1080/14623520601056240 
Woodhead, M. (1999). Reconstructing developmental psychology—some first steps. Children \& Society, 13, 3-19. https://doi.org/10.1111/j.1099-0860.1999.tb00097.x

Yakushko, O. (2019). Eugenics and its evolution in the history of western psychology: A critical archival review. Psychotherapy and Politics International, 17, 1-13. 
Figure 1

Photo of the Two Row Wampum Belt

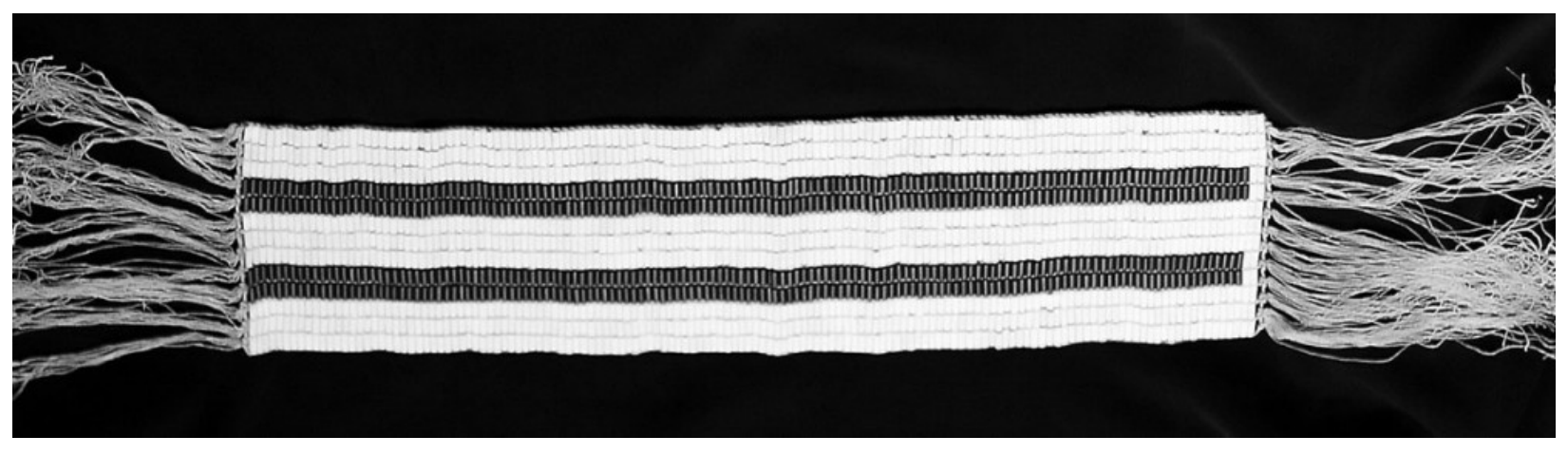

Note. NativeMedia, CC BY-SA 4.0, via Wikimedia Commons 
Figure 2

Sketch of the Life Course, Haudenosaunee Developmental Science, and Mainstream Developmental Science as Conceptualized by the Two Row Wampum

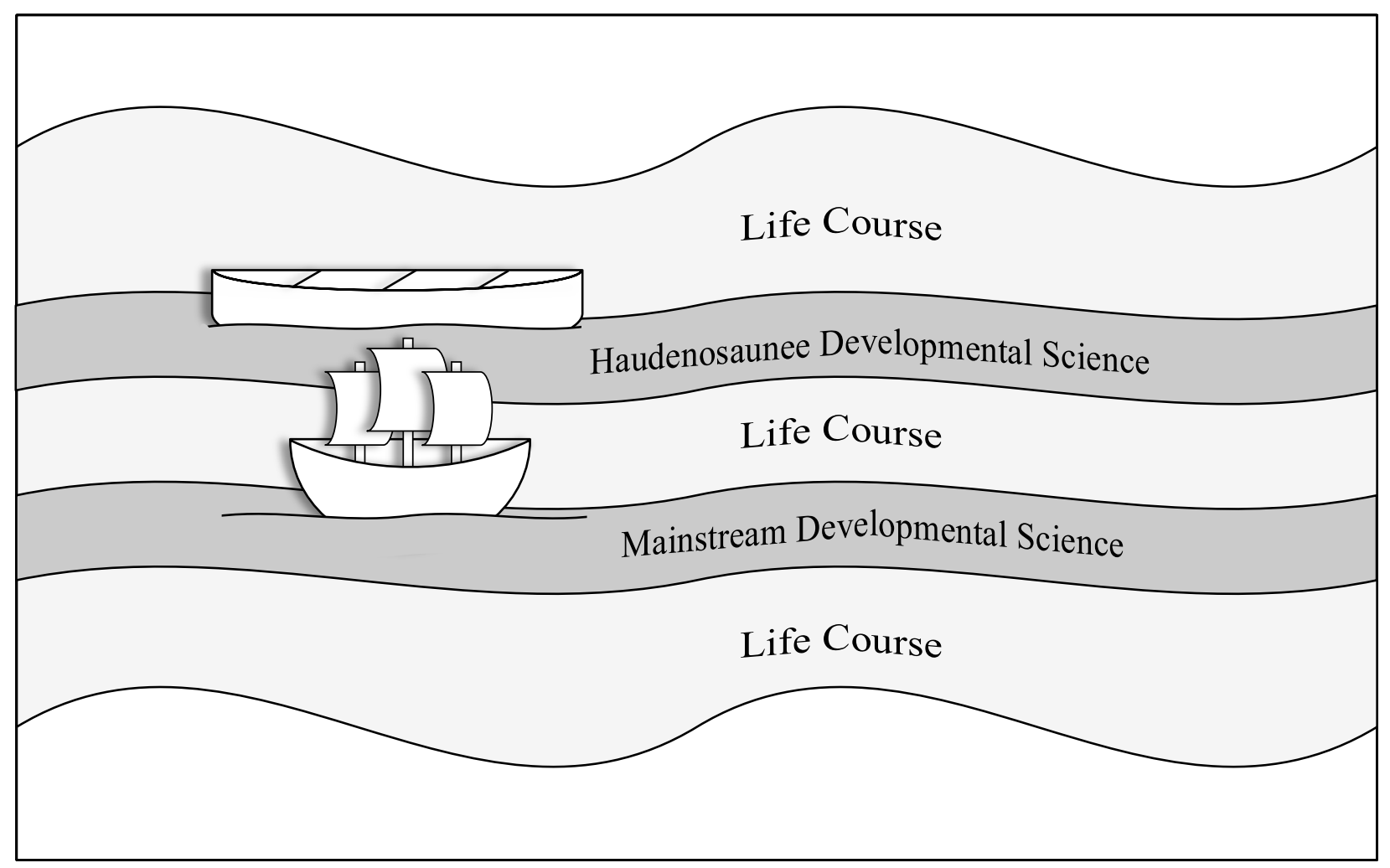


Figure 3

Sketch of Haudenosaunee Developmental Science in a River Channel and Mainstream Developmental Science Dominating the Main River as Conceptualized by the Betrayal of the Two Row Wampum

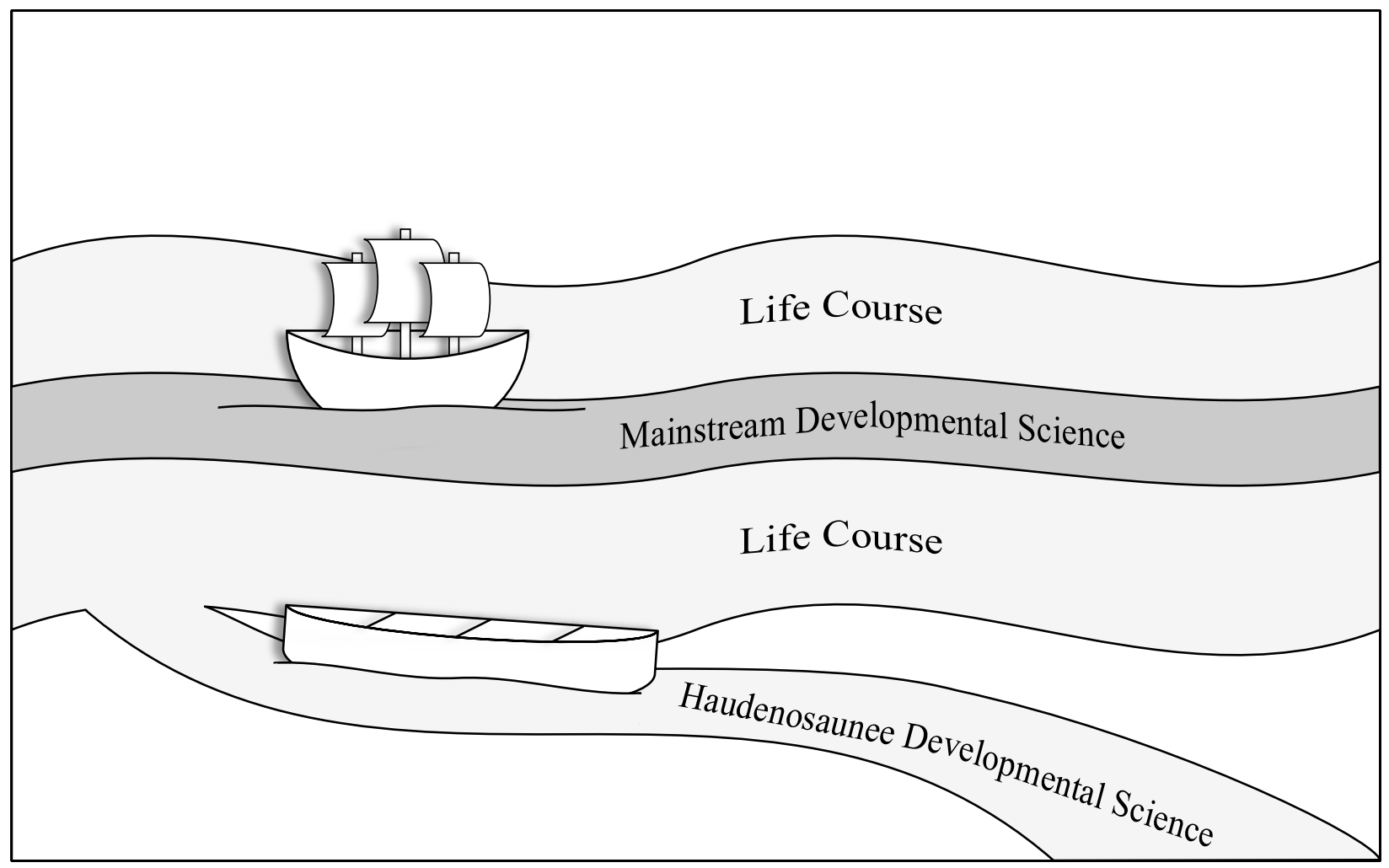

